\title{
Comparative Study in Central and Eastern Europe Regarding Restitution/Compensation
}

Process

\author{
Ph. D. Cand. Saida Bejtja \\ Aleksander Xhuvani” University, Faculty of Economics, Department of The right, Elbasan, Albania. E mail: \\ saida.muca@live.com
}

Ph. D. Cand. Dritan Bejtja

"Aleksander Xhuvani" University, Faculty of Economics, Department of Business -Administration, Elbasan, Albania. E mail: dbejtja@live.com

\begin{abstract}
The aim of this paper is to analyze the transformations that occurred in the area of private property ownership following the change of political regime in former socialist or communist countries. The six countries looked at are: Albania, Bulgaria, Croatia, Romania and Serbia. These countries illustrate well the whole range of contentious problems in a region where the Communist regimes have varied tremendously in their approach to private property, intensity of social control, repression and overall legitimacy. This diversity of situations poses today different types of dilemmas for the property restitution process, dilemmas which are approached by each country in a different manner. The main question for the countries is how an emerging democracy can "respond to public demands for redress of the legitimate grievances of some without creating new injustices for others. "Moreover, property rights and transparency represent the very bases of a functioning market economy: each of the countries faces the difficult task of finding a balance between remedying violations of property rights and guaranteeing a functioning land market, which enables or will enable full freedom of movement of capital in the EU. There are a number of fundamental difficulties and dilemmas regarding nationalization and restitution/compensation policies in the post-Communist governments in Albania, Bulgaria, Romania and the Western Balkans had to face.
\end{abstract}

Keywords: property, restitution, rights, dilemmas, process.

\section{Country-by-Country Summary of Property Restitution in Central and Eastern Europe}

Albania Immovable property Rights Reform in the 1990s

The concept of private property ownership was revived in Albania after the fall of communism through a broad, but inconsistent, privatization process.

Prior to World War II, much of the immovable property in Albania was privately owned and included in an indigenous land registry established in the 1930s. All immovable property was progressively nationalized under communism. In 1991, the newly elected parliament reintroduced private immovable property ownership and reactivated the immovable property registry. Particularly important was the 1991 Law On Land, under which agricultural lands were divided among those working them and their families-some two-thirds of the population in total. All former cooperative farms were distributed as part of this process, although the details of implementation varied from region to region. This uneven approach gave rise to frequent disputes, which the local authorities were typically unable to resolve. Ineffective law enforcement increasingly led the population to question the authority of the state and the law. In urban areas, a 1992 Law On Privatization of State-Owned Housing ensured that occupiers obtained ownership of their homes. Some 440,000 apartments and houses were privatized under this law. Table 1 provides a summary of key legislation on property rights in Albania. 
Table 1: Brief Chronology of Immovable property Rights Reforms

\begin{tabular}{|c|c|}
\hline Early 1990s & $\begin{array}{l}\text { Immovable property privatization } \\
\text { - Law No. } 7501 \text { of July } 19,1991 \text {, On Land, under which agricultural lands were divided } \\
\text { among those working them. } \\
\text { - Law No. } 7652 \text { of December } 23,1992 \text {, On Privatization of State-Owned Housing } \\
\text { transferred to occupiers ownership of their homes. } \\
\text { - Law No. } 7698 \text { of April } 15,1993 \text {, On Restitution and Compensation to Former Property } \\
\text { Owners was the basis for further privatization in urban areas. }\end{array}$ \\
\hline Mid-1990s & $\begin{array}{l}\text { Civil law reform, particularly under the Civil Code of } 1994 \text {, provided a legal framework for } \\
\text { private property transactions. }\end{array}$ \\
\hline 1995 & Law No. 7843 of July 13, 1994, On the Immovable Property Registry System. \\
\hline 1998 & Constitution adopted, including provisions guaranteeing immovable property rights. \\
\hline 2004 & $\begin{array}{l}\text { Law No. } 9404 \text { of October 29, 2004, On Legalization and Urban Planning of Informal Zones } \\
\text { attempts to regularize illegal buildings based on a self-declaration process managed by local } \\
\text { authorities. }\end{array}$ \\
\hline 2004 & $\begin{array}{l}\text { Law No. } 9235 \text { of July 29, 2004, On Restitution and Compensation of Property replaces the } \\
1993 \text { law and introduces compensation at current market value. }\end{array}$ \\
\hline 2006 & $\begin{array}{l}\text { Law No. } 9482 \text { of April 3, 2006, On Legalization, Urban Planning and Integration of Illegal } \\
\text { Constructions replaces the } 2004 \text { law and attempts to regularize illegal settlement and } \\
\text { buildings constructed before May 2006, subject to a self-declaration process managed by } \\
\text { the central Agency for the Legalization, Urban Planning, and Integration of Informal Areas/ } \\
\text { Constructions (ALUIZNI). }\end{array}$ \\
\hline 2007 & $\begin{array}{l}\text { Law No. } 9780 \text { of July } 16,2007 \text {, On Construction Inspection delegates much of the } \\
\text { responsibility for dealing with illegal buildings to the local government. }\end{array}$ \\
\hline 2009 & $\begin{array}{l}\text { 1. Law No.10119 of April 23, 2009, On Territorial Planning introduces modern concepts } \\
\text { of urban planning and control. The secondary regulations were adopted in June } 2011 . \\
\text { Amendments to the Law on Legalization, adopted in October 2009, give legalization } \\
\text { applicants the option of paying for up to } 50 \text { percent of the value of the property with } \\
\text { otherwise worthless privatization vouchers from the } 1990 \text { s. }\end{array}$ \\
\hline
\end{tabular}

The first step in introducing a modern property registration system was taken in 1994, but the process of first property registration remains incomplete.

The Law on the Registration of Immovable Property adopted in 1994 provides for a modern, parcel-based registration system, and established a dedicated agency, the Immovable Property Registration Office (IPRO) for managing this process. Since then, various donor-sponsored projects have worked to register immovable property in a systematic manner, including the World Bank-financed Land Administration and Management Project (LAMP). Due to the lack of a nationwide effort aimed at systematic first registration, IPRO now estimates that it has records for some 60-70 percent of all properties. IPRO has completed first registration for 83 percent of rural cadastral zones, but only 25 percent of urban cadastral zones. As a result, most properties in urban areas still remain unregistered, though first registration in these areas is currently underway with support from the LAMP.

\section{It is estimated that some 350,000 to 400,000 buildings have been erected without permits nationwide.}

Rapid internal migration during the economically turbulent, yet less restrictive, 1990s led to mass squatting on state and private land-especially in coastal and periurban areas. No official mechanism existed to allocate land for such large numbers of migrants, so people simply occupied land and started to build. Land was carved up informally, but much of it remained classified as agricultural land and thus ineligible for construction permits. Construction took place without regard for planning or building laws, without official approvals, without proper infrastructure, and often (but not always) on land that 
did not belong to the builder. As a result, many urban properties are regarded as illegal. The lack of effective planning and construction controls facilitated additions and expansions of existing constructions that are now also considered illegal. Illegal constructions are estimated to make up one-third of the total housing stock and to have cost some $€ 10$ billion to build. Approximately one-third of the land on which illegal buildings have been constructed belongs to the builders, onethird to the state, and one-third to another person, such as an owner whose property was restored or a person who received land under the 1991 Law On Land. Table 2 outlines circumstances that result in illegal status. The institutional structure for property rights in Albania is laid out in Table 3.

Table 2: Status of Properties in Albania

\begin{tabular}{|c|c|c|}
\hline Status & Issues & Consequences \\
\hline $\begin{array}{l}\text { Registered property with } \\
\text { clear title and boundaries }\end{array}$ & $\begin{array}{l}\text { Property is registered at IPRO with- } \\
\text { out restriction and boundaries are } \\
\text { not in dispute }\end{array}$ & $\begin{array}{l}\text { Registered property may be sold, mortgaged, or receive } \\
\text { compensation in case of expropriation; may be sold at } \\
\text { about a } 10 \text { percent higher price than an equivalent prop- } \\
\text { erty without registration or with unclear title. Law offers } \\
\text { protection. }\end{array}$ \\
\hline $\begin{array}{l}\text { Unregistered property with } \\
\text { clear title and boundaries }\end{array}$ & $\begin{array}{l}\text { Documentary proof of ownership } \\
\text { exists and boundaries are not dis- } \\
\text { puted, but property is not registered } \\
\text { at IPRO }\end{array}$ & $\begin{array}{l}\text { Cannot be mortgaged, difficulties in expropriation (has } \\
\text { to be registered first), unappealing to foreigners, nota- } \\
\text { ries not involved in sale. Property can be registered sub- } \\
\text { ject to applicable fees and legal costs. }\end{array}$ \\
\hline $\begin{array}{l}\text { Registered property with } \\
\text { unclear title }\end{array}$ & $\begin{array}{l}\text { Some problems or uncertainty exist } \\
\text { regarding legal rights, such as miss- } \\
\text { ing documents }\end{array}$ & $\begin{array}{l}\text { Requires effort and costs to resolve problem, possibly } \\
\text { court case. Some difficulties in mortgaging, selling. }\end{array}$ \\
\hline $\begin{array}{l}\text { Unregistered property with } \\
\text { unclear title (or boundaries) }\end{array}$ & $\begin{array}{l}\text { Property could not be registered } \\
\text { due to uncertain ownership }\end{array}$ & $\begin{array}{l}\text { Requires effort and costs to resolve problem, possibly } \\
\text { court case, plus costs of registration. Cannot be mort- } \\
\text { gaged; difficulties in expropriation; more difficult to sell, } \\
\text { especially to foreign buyers; notaries not involved in sale. }\end{array}$ \\
\hline $\begin{array}{l}\text { Land occupied by squatters } \\
\text { and illegally built on, but } \\
\text { successfully legalized }\end{array}$ & $\begin{array}{l}\text { After legalization by ALUIZNI and } \\
\text { title registration at IPRO, property } \\
\text { has the same status as registered } \\
\text { property with clear title and bound- } \\
\text { aries }\end{array}$ & $\begin{array}{l}\text { Same as for registered property with clear title; during } \\
\text { the legalization process, legal protection unclear (e.g., in } \\
\text { case of expropriation, as property needs to be registered } \\
\text { first). }\end{array}$ \\
\hline $\begin{array}{l}\text { Land (registered or not) } \\
\text { with illegal building }\end{array}$ & $\begin{array}{l}\text { Occupier is legal owner of land } \\
\text { (may nor may not be registered) but } \\
\text { building does not have construction } \\
\text { permit; or building does not comply } \\
\text { with terms of construction permit } \\
\text { (for example, has additional floors) }\end{array}$ & $\begin{array}{l}\text { Owner at risk of having building demolished; problems } \\
\text { with expropriation, sale; property cannot be mortgaged } \\
\text { if land is not registered. }\end{array}$ \\
\hline $\begin{array}{l}\text { Land belonging to a differ- } \\
\text { ent owner (registered or } \\
\text { not) and illegally occupied } \\
\text { by squatters; not part of the } \\
\text { legalization process }\end{array}$ & $\begin{array}{l}\text { Mass migration resulted in large- } \\
\text { scale occupation of land and } \\
\text { construction without legal title or } \\
\text { planning permit; not all occupiers } \\
\text { have applied for legalization; } \\
\text { some properties are not eligible for } \\
\text { legalization (including land in desig- } \\
\text { nated natural reserves) }\end{array}$ & $\begin{array}{l}\text { Least secure category: owner is at risk of eviction or de- } \\
\text { molition of building. Property cannot be mortgaged or } \\
\text { legally transferred; no legal protection in case of expro- } \\
\text { priation. }\end{array}$ \\
\hline
\end{tabular}


Table 3: Key Institutional Actors on Property Rights

\begin{tabular}{l|l}
\hline Organization/Agency & \multicolumn{1}{|c}{ Mandate } \\
\hline IPRO & $\begin{array}{l}\text { To register immovable property, transaction documents, and changes to boundaries, and to } \\
\text { supply data to the public }\end{array}$ \\
\hline ALUIZNI & $\begin{array}{l}\text { To coordinate with planning authorities on the introduction of illegal buildings into urban plans } \\
\text { and to grant ownership of occupied land to squatters who are legalizing their building }\end{array}$ \\
\hline AKKP & $\begin{array}{l}\text { To manage the restitution of land or provide compensation in cash or through alternate } \\
\text { properties or other means }\end{array}$ \\
\hline $\begin{array}{l}\text { Municipalities and } \\
\text { Communes }\end{array}$ & To develop and issue urban plans and approve projects up to 5,000 square meters \\
\hline $\begin{array}{l}\text { National Council for } \\
\text { Territorial Adjustment }\end{array}$ & $\begin{array}{l}\text { To develop and issue plans at the national level and approve projects larger than 5,000 square } \\
\text { meters }\end{array}$ \\
\hline $\begin{array}{l}\text { Construction Police } \\
\text { (national and local level) }\end{array}$ & To investigate, fine offenders, and take remedial action, such as demolishing structures \\
\hline
\end{tabular}

The current problems are not intractable and can be addressed through a coherent policy aimed at a comprehensive and pragmatic solution, based on broad political and societal support.

Such a solution would need to address some important inconsistencies and gaps in the existing legal framework to remove current bottlenecks holding back the key processes of title registration, legalization, and restitution and compensation. In particular, a policy solution whereby a greater share of the cost of compensation would originate from beneficiaries of expropriation (such as legalization applicants) would likely be more sustainable, both in terms of fiscal affordability and perceived fairness. An acceleration in the payment of compensation to expropriated owners is urgently needed to ensure credibility of the law, stem the flow of legal challenges, and remove obstacles to the completion of the legalization process. At the same time, this may require revisiting the legal provision to pay compensation at current market values, which is not in line with international practice. A comprehensive solution will also need to consider the status of a large number of informal properties that currently remain outside the legalization process and clarify the legal rights of legalization applicants while the process is ongoing. An open debate with the active participation of all stakeholders and civil society at large will be instrumental to finding a viable solution that is seen as legitimate, equitable, and sustainable over the longer term. The Government's Action Plan for the Resolution of Property Rights Issues, which was adopted in April 2011, aims to accelerate the payment of compensation to restitution claimants and address related aspects of the legalization and title registration processes. While the Action Plan represents a positive step toward a policy debate on a sustainable solution, a comprehensive Strategy still remains to be prepared.

\section{A successful solution will also require a strong focus on ensuring effective and consistent implementation of policies and laws.}

In this regard, the Government will need to continue its efforts to further strengthen the capacity of IPRO and seek to speed up the systematic completion of first registration in urban centers and other economically significant areas to improve the validity of IPRO records. It will also be important for the Government to act with determination to enhance coordination among IPRO, ALUIZNI, and AKKP, possibly by amalgamating these agencies or subordinating them to the supervision of a single cabinet member. Indeed, the Government's Action Plan of April 2011 foresees a new coordination mechanism. At a minimum, it will be necessary to ensure the full compatibility between these agencies data, information requirements, and procedures. Finally both the Government and civil society will need to loosely monitor the effective and consistent implementation of the new Urban Planning Law as well as municipal authorities' practices in issuance of construction permits, which have hitherto been fraught with uncertainties and corruption opportunities.

\section{Bulgaria}

- Most private property claims have been settled. 
- A Government Commission made recommendations in 2006 to resolve outstanding communal property claims.

\section{Private Property}

Bulgaria was one of the first Eastern European countries to pass private property restitution legislation. In contrast to other former communist countries, Bulgaria did not generally nationalize land, but instead nationalized businesses using the land while owners retained title to the land itself. Current restitution law stipulates that both Bulgarian citizens and non-Bulgarian citizens are eligible to receive property confiscated during the fascist and communist periods. A successful claimant who is not a Bulgarian citizen, however, must sell the property. Only Bulgarian citizens can receive restituted forest and farmland. Most private property claims have been resolved.

\section{Communal Property}

NGOs and certain denominations, including the Bulgarian Orthodox Church, the Catholic Church, the Muslim community, the Jewish community, and several Protestant churches, claim that a number of communal properties confiscated under the communist government have not been returned. In this category is a Muslim community claim for at least 17 properties. The Catholic Church claims six buildings in Sofia, three buildings in Plovdiv, several buildings in other towns, and three monasteries. In addition, the government reportedly retains properties of several Protestant groups. The Congregational Church, for example, has an ongoing dispute with the municipality over a building in Plovdiv.

In the spring of 2006, the Government appointed a commission to examine the status of several properties claimed by Shalom, the Bulgarian Jewish community organization. These properties had been under discussion between Shalom and the Government for more than a decade. One property that was not on the commission's agenda was the property on which the Rila Hotel is situated. A court ruling in early 2006 rejected the long-contested claim of the Bulgarian Jewish Organization, Shalom.

In regard to the other properties claimed by Shalom, the Commission recommended that alternate property be identified to turn over to Shalom to replace a synagogue and rabbi's residence in Varna. With respect to a Sofia hospital restituted to Shalom in 1997 and leased to a state hospital, the Commission suggested speeding the process of finding suitable quarters for the hospital and transferring six rooms of the existing hospital to Shalom. Despite the Government's recommendation, however, the hospital's management, which ceased rental payment in 2002, has neither transferred the rooms to Shalom nor has it agreed to a date for vacating the premises in the future.

In 2003, the government restituted to Shalom all but the top two floors of the building at 9 Saborna Street in Sofia. After confiscating the building, the government added the top two floors, which were therefore not eligible for restitution. In 2007, the government decided to gift the top two floors to Shalom.

A central problem facing all claimants of communal property is the need to demonstrate that the claiming organization (or its legitimate successor) is the organization that owned the property prior to September 9, 1944. Destruction of records during the war and the effort by some groups to conceal ownership of assets because of communist hostility to religion have complicated the documentation of ownership.

\section{Croatia}

- $\quad$ Stalled legislation slows pace of private property restitution.

- $\quad$ Communal property claims remain largely unresolved. 


\section{Private Property}

Due to Croatia's turbulent past, there is a large amount of disputed property throughout the country. Croatia passed a property restitution law in 1990, and subsequently amended that law in 1991 and 1993. Implementation of the law continues to proceed very slowly.

The 1996 "Law on Restitution/Compensation of Property Taken during the Time of the Yugoslav Communist Government" prohibited non-Croatian citizens from making claims. But in a 1999 ruling, the Constitutional Court struck down six clauses deemed to discriminate against foreigners. After a long delay, the Croatian parliament in July 2002 amended the law to extend to foreigners the right to claim nationalized property or receive compensation, provided that Croatia and the claimant's home country have concluded a bilateral agreement on the issue. The amended law pertains to the communist era only and not to the 1941-45 period of rule by the Nazi-allied Ustashe regime, nor to the period of civil unrest after the breakup of Yugoslavia.

The law initially created a six-month period from July 2002 until January 2003 in which non-Croatian citizens were eligible to file claims. Croatia subsequently waived that deadline after determining that it does not have an appropriate bilateral agreement with the U. S. or any other country that would allow non-Croatian citizens to file claims. The government did not provide any official response to U. S. requests during 2004 and 2005 to negotiate such an agreement. In late 2005, Croatia concluded an agreement with Austria that would have enabled Austrian citizens to apply for property restitution. That agreement was not submitted for ratification.

In early 2006, the Croatian government informed the U. S. Embassy that Croatia had decided it would not pursue further bilateral agreements. At that time the Croatian government instead proposed amending the 1996 law in order to allow foreigners to file claims under the Act's provisions without the need for a bilateral or international agreement governing the issue. Under the amendment, foreigners would be given a six month period to file claims, and the law would allow the inclusion of claims for property taken as early as 1941. As of September 2007, that amendment had not yet moved forward in Croatia's parliament, leaving non-Croatians still unable to apply for restitution under the 1996 law.

A number of individuals, who were not U. S. citizens when their claims against Croatia arose but have since become American citizens, are among those foreigners with outstanding property claims.

Two previous U. S. -Yugoslav settlement agreements compensated many claims by American citizens. The first agreement pertained to property expropriated between 1939 and 1948. The second agreement, entitled the "Agreement between the USG and SFRY Regarding Claims of US Nationals", became effective on January 20, 1965 and covered the years from 1948 to 1964 . Both agreements applied to claimants who were U. S. nationals at the time the property was seized. The claims process under these two agreements ended in the 1960s.

The issuance of permits by local governments for construction on land with disputed titles complicates the restitution process.

\section{Communal Property}

The government has worked separately with the various religious communities to resolve communal property restitution issues. Usually agreements between the government and the individual communities govern the communal property restitution process. So far, agreements have been signed with the Catholic, Serbian Orthodox, and Muslim communities, but not with the Jewish and Baptist communities. The government maintains that 19 percent of all communal property restitution claims have been resolved.

The government employs three methods to restitute communal property to religious communities: natural restitution (in rem restitution of the actual property that was taken), replacement restitution (transfer of like-kind property when the original property cannot be restituted), and monetary compensation.

Of all the religious communities, the Catholic Church is the largest holder of property. In 1998, the government signed a concordat with the Vatican that provided for the return of all Catholic Church property confiscated by the communist regime after 1945. This agreement stipulates that the government would return seized properties or compensate the Church where return is impossible. Some returnable properties have been restituted, but there has been no compensation to date for non- 
returnable properties. In April 2003, the Catholic Church specifically requested the restitution of 43 properties, but three years later only a few of those properties had been restituted. Many claims met resistance from local authorities.

In exchange for nationalized property, the Church took over a former hospital building in Osijek in June 2004 and in September it renounced claims on its building used by the University in Rijeka in exchange for another University building. In 2006, the Roman Catholic Church received eight separate properties in restitution proceedings. A Government offer of a 25 percent stake in the Croatia Osiguranje insurance company as compensation for unreturned property remains under negotiation.

The Serbian Orthodox (SPC) community filed hundreds of requests for the return of seized properties, but the community has received only ten percent of what it claimed. An agreement between the Orthodox community and the government established a commission to address property claims. Several properties at issue in Zagreb are the subject of court cases, which take many years to adjudicate. In 2004 one building in Karlovac was returned, which housed County offices. Return of forests and arable land is particularly slow.

The Serbian Orthodox Church held three meetings with government representatives on restitution issues in 2007 but the results were minimal. Early in 2007 Metropolitan Jovan Pavlovic asked both the U. N. High Commissioner for Refugees and the Organization for Security and Cooperation in Europe to propose changes to the 1996 property restitution law. No further action has been taken.

SPC officials were particularly concerned about the lack of progress in restitution of several valuable business and residential buildings in downtown Zagreb, most notably the Zagreb Cinema building and several apartments which have been the subject of contentious legal proceedings, some undeveloped land, as well as some arable land and forests. .

The Jewish community in Croatia before World War II numbered approximately 35,000 to 45,000 . Some 6,000 Croatian Jews survived the war, and the community now has about 2000 members, more than half of whom live in Zagreb. Although Jewish groups in Croatia have received some of their claimed property in Zagreb, several outstanding claims remain. For example, land in Vukovar where a synagogue was once located has been returned to the Jewish community, but an estimated 20 additional Jewish property claims are still pending throughout the country. The Jewish community is in the process of negotiating an agreement with the government to address property restitution, and other issues. The Jewish community reported that the processing of its claims for nationalized property has made no progress since 2005 , with the exception of the 2007 return of a commercial property in Osijek. Other claims remained stalled in court.

The Muslim community of approximately 60,000 has not filed any claims. It is not clear whether the Protestant churches have claimed any property.

\section{Romania}

- Implementation of Law 10/2001 (private property) continues at a slow pace.

- Implementation of Law 501/2002 (religious property) and Law 66/2004 (communal property) began late, and is proceeding slowly.

- $\quad$ Property fund not yet operational.

- $\quad$ Greek Catholic Church claims remain unresolved.

\section{Private Property}

Romania did not pass formal property restitution legislation until 2001 for urban dwellings (legislation was passed regarding farm and forest lands in 1991 and 2000, respectively). For the first decade following the fall of the Ceausescu regime, a series of court decisions, laws and decrees governed the return of property seized during World War II and under communist rule. These decisions, laws and decrees were frequently contradictory and led to considerable confusion.

In February 2001, Romania enacted Law 10 to govern private property restitution for properties confiscated during the 1945-1989 period. While this law provides a systematic approach to private property restitution, it is complex and places a considerable burden on claimants. Initially, the law provided an application period of just six months. There was no notification program outside of Romania, so potential claimants found it difficult to learn about the application process. 
At the suggestion of the United States, the Romanian government extended the deadline, first to November 2001 and then to February 14, 2002. But the overseas notification program was not implemented until late 2001, making it hard for claimants to meet the application deadline. Law 10 does not allow for the restitution of agricultural or forested properties, which were covered by laws 18/1991 and 1/2000. Nor does Law 10 cover the restitution of properties belonging to religious communities or minority groups. Article 16 of Law 10, which exempted properties used for public purposes (such as hospitals, schools, kindergartens, theaters, museums, and other such institutions) from restitution in rem, was amended by Law 247/2005 to allow the restitution of such buildings. The rightful owners have the obligation to let public and cultural institutions use the buildings as tenants for three years, and health care and educational institutions for five years, after the restitution of the buildings. The owners are exempted from property taxes during this period and receive rent.

Law 10 required that applicants submit claims to municipal authorities through a court having jurisdiction over the property in question. This made it difficult for applicants who left Romania at an early age or for heirs to know where to submit applications. Despite these hindrances, about 202,000 claims were filed; of these, 120,000 claimants requested restitution in kind and 82,000 requested financial compensation or other reparation measures. Only 38,400 applications were completely documented. The National Authority for Property Restitution (ANRP) reported that approximately 97,000 claims had been resolved by mid- 2007 .

The deadline for documenting claims was extended from February 14 to July 1, 2003. In May 2003, the government published reformulated implementing regulations. The late publication gave applicants little time to comply prior to the July 1 deadline. These regulations provide that individuals who "sold" their property to the communist-era government in order to emigrate would not be compensated. Claimants also had to submit official documentation showing that they did not receive any compensation under prior claims agreements (such as the 1955 and 1963 U. S. -Romania Claims agreements).

In July 2005, the Romanian government passed Law 247 aimed at improving the property restitution process, clarifying and simplifying procedures, establishing new deadlines for submitting applications for the restitution of religious and communal property (January 25, 2006), as well as of farm and forest land (November 30, 2005), and fines for officials who hindered the process. The 2005 law eliminated some of the flaws of earlier property restitution legislation that were repeatedly criticized, e. g. , among others, it permits the restitution of land on which now demolished buildings once stood, and provides for compensation.

Law 247/2005 amended all the existing restitution laws, i. e. law 10/2001, law 501/2002, law 66/2004, and the land restitution laws.

Law 247/2005 eliminated the deadline (originally July 1, 2003) for the submission of documents supporting the applicant's claim. Claimants can continuously submit newly obtained documents and proof of ownership until a case is resolved.

Law 247/2005 also created a fund equivalent to Euros 4 billion (\$5. 3 billion) in registered capital to compensate owners whose property cannot be returned. Payment for property that cannot be restituted will be in the form of shares in a government-supervised investment fund comprising 114 companies. As of September 2007, 2,457 claimants had received shares. These shares, however, cannot yet be legally traded. As of September 2007, some $97 \%$ of the fund was still owned by the state.

On June 28, 2007, the government adopted an ordinance that should enable the fund to be evaluated and then listed on the stock exchange by mid-2008. The ordinance also provides for cash payments in lieu of restitution of up to about $\$ 215,000$ (500,000 new lei), paid over a two-year period. Larger claims are to be paid with stock in the property fund. Other steps that have been scheduled for 2007 are the assessment of the stock comprising the Fund's portfolio and, perhaps most importantly, the selection of a firm with an international reputation to manage the Fund. At the end of 2006, 31 different international firms were interested in becoming the Fund manager.

Former owners criticize the Property Fund as being only a means to delay further the compensation of property seized under communist rule.

It is not clear how long it will take to adjudicate claims or how transparent that process will be. Claimants reported that local officials are reluctant to provide necessary documents and frequently delay or refuse to turn over properties in which local governments had an interest. Furthermore, some mayors charged with adjudicating claims were reported to be pushing claimants to accept shares in the fund instead of in rem restitution in order to avoid the political and administrative difficulties 
associated with displacing current occupants. There were also complaints that the central government was inconsistent in imposing fines and other sanctions in such cases.

In numerous Romanian property restitution cases over the past several years, the European Court of Human Rights has ruled in favor of the former owners. There were at least eight such cases in the first five months of 2007. In each case, the Court has ordered the Romanian state to pay sizeable damages unless the buildings in question were returned.

\section{Communal Property}

In late June 2002, Parliament approved Law 501/2002 governing the restitution of property to religious organizations. The law covers buildings (such as schools and hospitals, but not houses of worship) that the State confiscated from religious groups between March 6, 1945 and December 22, 1989. It did not cover the period between 1940 and 1945, when large numbers of Jewish properties were seized, nor does it cover the restitution of Greek Catholic churches confiscated by the former communist regime and now held by the Romanian Orthodox Church. Unlike Law 10, it covers only buildings that still exist and does not provide compensation for buildings that were demolished. Under Law 501/2002, religious denominations had requested restitution of 7,568 properties by the original March 2, 2003 deadline. By the time the extended filing period (January 25,2006 ) lapsed, the number of applications reached 14,716 , broken down as follows:

\begin{tabular}{|l|l|}
\hline Orthodox Church & 2,215 \\
\hline Roman-Catholic Church & 1,203 \\
\hline Greek Catholic Church & 6,723 \\
\hline Reformed Church & 1,208 \\
\hline Jewish faith & 1,918 \\
\hline Evangelical Church & 1,133 \\
\hline Other denominations & 303 \\
\hline
\end{tabular}

Under Law 501/2002, by the middle of 2007, the Special Commission for Restitution had restituted 599 of the 1700 buildings claimed by Hungarian churches. However, the Hungarian churches were not able to regain physical possession of many of these properties.

A foundation established by the Federation of Jewish Communities in Romania and the World Jewish Restitution Organization to follow restitution issues has received approximately 42 properties, restituted by the four government acts passed between 1997 and 2000. The Jewish community was able to take actual possession of only 36 of them. Documenting ownership has been difficult for the foundation because of the lack of access to archives. As of mid-2007, the Jewish community had received only 51 of the 1,918 properties claimed under Law 501 . For 16 other properties, the Jewish community will receive compensation. In addition, under Laws 18/1991 and 1/2000, the Jewish community received 15 pieces of land in lasi (sites of former synagogues and schools). Three additional plots were returned to the Jewish community in 2005 and 2006, but 18 other land claims remained unresolved.

In March 2004, Parliament adopted Law 66 covering the restitution of properties that belonged to ethnic communities and were confiscated between September 6, 1940 and December 22, 1989. Confiscation between 1940 and 1945 was included at the suggestion of the Jewish community. By the filing deadline-which was extended to January 25, 2006-2,154 claims were filed, 1,856 by the Jewish community alone. As with Law 502 , there is no provision for compensation for demolished buildings. Actual restitution under this law began in 2006 and 156 claims were resolved by June 1, 2007.

A 1990 government decree established a joint Orthodox and Greek Catholic committee to address the issue of former Greek Catholic churches. The committee met only sporadically in the 1990s and its work has been at a virtual standstill 
since 2004. There were 2600 properties (churches and monasteries) on the original list of Greek Catholic claims. By the middle of 2005, the Greek Catholic Church had reduced its claims to fewer than 300 . The Greek Catholics report that only 16 churches have been restituted as a result of the joint committee's work. The Orthodox Church has continued to demolish Greek Catholic churches under various pretexts.

Of the 6,723 properties claimed by the Greek Catholics under Law 501/2002, 103 had been returned by mid-2007. In eight other cases, the Greek Catholic Church will receive compensation. Since 1989, fewer than 200 churches have been returned to the Greek Catholics. The Greek Catholic Church, however, did obtain an important cathedral in Oradea in November 2005 with the help of interventions from the Prime Minister and the Minister of Culture and Religious Affairs, and a cathedral in Satu Mare in February 2006, after 16 years of lawsuits.

Lawsuits and protests by current occupants have impeded the restitution of many properties to their rightful owners.

Serbia:

- $\quad$ Private property restitution has not begun, pending passage and implementation of necessary laws.

- $\quad$ Communal property restitution law awaits implementation.

\section{Private Property}

Many American citizens with claims in Serbia received compensation under two settlement agreements concluded between the United States and Yugoslavia in 1948 and 1965. The 1948 agreement pertained to property expropriated between 1939 and 1948; the 1965 agreement covered property seized between 1948 and 1964. The claims processed under these agreements ended in the 1960s. Under these agreements, the Socialist Federal Republic of Yugoslavia (SFRY) paid a total of $\$ 20.5$ million. The two agreements do not hold Yugoslavia or its successor states harmless from additional claims of current American citizens. The agreements provided access to settlement to claimants who were American citizens at the time their property was taken. Under Serbian law, heirless property reverts to the state.

The military conflict of the 1990s delayed consideration of property restitution legislation in many of the former Yugoslav republics. Serbia does not yet have restitution legislation. However, a law providing for the registration of potential claims went into effect on June 8, 2005. The law covers property taken through confiscation, nationalization, agrarian reform, sequestration, expropriation and other regulations that became effective after March 9, 1945. The legislation set a June 30, 2006 registration deadline, and allowed deprived owners, their legal inheritors or legal successors to register claims. According to the law, registering a claim for seized property does not represent a request for restitution or compensation for that property. The Embassy is concerned that the 1945 date may disadvantage Jewish claimants who generally had property seized prior to that date, and Jewish and Muslim groups have opposed this benchmark.

The most recent proposed draft law to govern the restitution of private property was presented by the interim government in May 2007, but was not accepted by the current administration. A Serbian government working group will begin revising that latest proposed draft law in early autumn 2007. The draft presented in the spring provides for regional commissions to adjudicate claims, awarding in rem restitution when possible and compensation in marketable bonds if the property is being used for a public purpose or has been purchased in good faith by an individual. Bond compensation would be limited to Euros 1 million per claimant and 1 million per property. The proposed draft law also provides for consideration of claims dating back to April 6, 1941. A number of claimants have objected to compensation in the form of bonds, the limit of Euros 1 million per claimant, as well as a number of other provisions in the draft law.

In addition to considering the various objections and suggested modifications to the latest draft, the government working group is also contemplating breaking the current proposed draft law into two separate laws: one on privatization of urban construction land and the other on general denationalization. Both could be approved by the end of the year in the most optimistic estimates.

The Finance Minister has publicly estimated the value of nationalized property in Serbia at between $\$ 60$ billion and $\$ 150$ billion, a daunting amount compared to Serbia's current total public debt of \$13 billion and \$23 billion GDP. 
Several U. S. citizens have raised ownership claims on commercial properties that are in the process of being privatized. The American Embassy in Belgrade is aware of 32 potential claims in Serbia involving U. S. citizens. These claimants were not able to benefit from previous legislation and/or bilateral agreements because they were not U. S. citizens when their claims arose. These claimants often accuse the Government of Serbia of delaying a restitution law until claimed assets have been sold.

Serbian officials have expressed concern that restitution would delay completion of privatization. Serbian law provides that $5 \%$ of all privatization revenues must be placed in a compensation fund for eventual restitution. The Embassy has raised restitution repeatedly with officials at the municipal, republic and state union levels, urging authorities to move ahead with a fair restitution law. Several EU member state embassies have also become engaged on behalf of their citizens.

\section{Communal Property}

In post-WWII Yugoslavia, religious communities were limited to possessing 10 hectares of land or 30 hectares of religious sites of cultural importance. In Serbia, a separate law is to regulate restitution of church and communal property.

In mid-2006, the Serbian National Assembly adopted the Law on Return (Restitution) of Property of Churches and Religious Communities, seeking to expedite the restitution of property to Serbia's religious communities. The law calls for the creation of a Restitution Agency, which will adjudicate claims.

With the exception of the Igumanova Palace, which was returned to the Serbian Orthodox Church by Milosevic as a goodwill gesture, no church properties have been restituted in Serbia.

\section{References}

1. Albania

[1] Agency for Restitution and Compensation for Properties, Report to the Prime Minister, 16. 10. 2009.

[2] Council of Ministers, Draft Inter-Sectoral Strategy Reform in the Field of Property Rights, Tirana, 2009.

[3] European Commission, Albania, Stabilisation and Association Report 2003, Brussels, COM (2003) 139 final, 26. 03.2003

[4] http: //ec. europa. eu/enlargement/pdf/albania/com03_339_en. pdf

[5] European Commission, Albania, Stabilisation and Association Report 2004, Brussels,

[6] COM (2004) 203 final, http: //ec. europa. eu/enlargement/pdf/albania/cr_alb_en. pdf

[7] European Commission, Albania 2005 Progress report, Brussels, COM (2005) 561 final 09. 11. 2005

[8] http: $\quad$ /lec. europa. eu/enlargement/archives/pdf/key_documents/2005/package/sec_1421_final_progress_report_al_en. pdf

[9] European Commission, Albania 2006 Progress Report, Brussels, COM (2006) 649 final, 08. 11. 2006

[10] http: //ec. europa. eu/enlargement/pdf/key_documents/2006/nov/al_sec_1383_en. pdf

[11] European Commission, Albania 2007 Progress Report, Brussels, COM (2007) 663 final, 6. 11. 2007

[12] http: //ec. europa. eu/enlargement/pdf/key_documents/2007/nov/albania_progress_reports_en. pdf

[13] European Commission, Albania 2009 Progress Report, Brussels, COM (2009) 533 final, 14. 10. 2009,

[14] http: //ec. europa. eu/enlargement/pdf/key_documents/2009/al_rapport_2009_en.pdf

[15] Frangakis, N. ; Salamun, M. and Gemi, E. "Property Restitution in Albania", Briefing Paper, Brussels, 2008.

[16] Interview with Mr. Toro, the representative of the Association of expropriated owners "Property through justice", Tirana, 27. 10. 2009 
[17] Kelm, K. Land Administration and Management Project Component A: Security of Tenure and Registration of Immovable Property Rights: Study on Security of Registered Titles in Albania. World Bank, Tirana, 23 October 2009.

[18] OSCE Presence in Albania. Commentary on the draft law "On Recognition, Restitution and Compensation of Property", presented to the Assembly of the Republic of Albania by OSCE led Technical Expert Group. 27 October 2003.

[19] http: //www. osce. org/documents/pia/2003/11/1434_en. pdf

[20] OSCE Presence in Albania. "OSCE Presence in Albania launches database on land restitution and compensation claims". Press release. Tirana, 27 June 2007.

[21] http: //www. osce. org/item/25342. html

[22] OSCE Presence in Albania, "Property reform" http: //www. osce. org/albania/18643. html

[23] OSCE Presence in Albania. Report by the Head of the OSCE Presence in Albania to the

[24] OSCE Permanent Council. October 2009. http: //www. osce. org/documents/pia/2009/10/40893_en. pdf

[25] Ministry of Justice. Annual Statistical Book 2008. http: //www. justice. gov. al/UserFiles/File/vjetari/Vjetari_Statistikor_2008. pdf

\section{Bulgaria}

[26] "Civil wars against each metre of new urban development" http: //www. segabg. com/online/article. asp?issueid $=2972 \&$ sectionid $=5 \& i d=0001001$.

[27] Gruev, Mihail. Preorani, Slogove. Kolektivizatziya i sotzialna promyana v Bulgarskiya severozapad 40-te - 50te godini na XX vek. Ciela, Sofia, 2009.

[28] Gyuzelev, Boyan. "Politika i privatizatziya. Transformatziya na sobstvenostta v Bulgaria prez prizmata na politicheskite borbi". Centre for the Study of Democracy (CSD), Sofia, 1993.

[29] Helsinki Committee, Watch Report "Destroying Ethnic Identity: The Turks of Bulgaria", September 1987.

[30] "Historic Victory in Agriculture', Rabotnichesko delo (official newspaper of the Communist Party) 1959.

[31] Interview with Mr. Ahmed Dogan, leader of the Turkish Ethnic Party MRF, Gledishta newspaper, reprinted in Duma daily on June 13, 1994.

[32] Kamm, Henry "Toll in Bulgaria's Turkish Unrest is put at 100", The New York Times, on Feb. 81985

[33] Mateev, B. Dvizhenieto za kooperativno zemedelie v Bulgariya v usloviyata na kapitalizma, Sofia. 1967.

[34] Ministry of Agriculture and Food, Annual Report 1999. Available at

[35] http: //www. mzh. government. bg/Article. aspx?lang=1\&lmid=421\&id=421\&rmid=0

[36] Ministry of Agriculture and Food, Annual Report 2000. Available at

[37] http: //www. mzh. government. bg/Article. aspx?/mid=420\&id=420\&lang=1

[38] National Statistical Institute. Results from Censuses. Vol. 1: Demographic characteristics. Sofia, 1994.

[39] National Statistical Institute, "Survey on the effects of the 1992 restitution laws". 2000.

[40] OECD, "Report on agriculture in Bulgaria", 2000.

[41] Panayotov, Filip, Nikolova, Ivanka. Bulgariya 20 vek: Almanakh, Trud Publ. , 1999.

[42] "Legal analysis", Praven svyat, http: //www. legalworld. bg/show. php?storyid=10425. Spasov, Spas. "Clockwork of a Ghetto", Dnevnik, 22 Apr 2007 
[43] http: //www. dnevnik. bg/dnevnikplus/2007/08/22/370441_geto_s_chasovnikov_mehanizum/

[44] State Privatisation Agency of Bulgaria, "Information on the privatisation process in Bulgaria (by 30.11. 2009)", available at www. priv. government. bg

3. Croatia

[45] Gagro B. , "Practice of the Administrative Court of the Republic of Croatia and Uncertainties in the Application of the Law on Restitution /Compensation of Property Taken During the Time of the Yugoslav Communist Government", report for the website

[46] of the Administrative Court,

[47] http: //www. upravnisudrh. hr/praksa/full. php?link=. . /praksanov/referat_bg. htm

[48] Interview with Milanovic, Petra, December 16th, 2009.

[49] Karadjova, M. , "Property Restitution in Eastern Europe: Domestic and International Human Rights Law Responses", Review of Central and East European Law, 2004 No. 3,325-363, Koninklijke Brill N. V. ,

[50] http: //web. ebscohost. com/ehost/pdf?vid=5\&hid=3\&sid=2c53af6c-51ec-41ba-91bb-

[51] 48dfa3f692a5\%40sessionmgr103\#db=poh\&AN=14614001

[52] Karlovcan, Djurović Lj. , "The Law on Restitution /Compensation for Property Taken During the Time of the Yugoslav Communist Government - Practice of the Administrative Court of the Republic of Croatia", Almanac of the Faculty of Law at University of Rijeka.

[53] Issue no. 29, March 2008, p. $643-679$

[54] http: //hrcak. srce. hr/index. php?show=clanak\&id_clanak_jezik=40006

[55] State Public Prosecutor's Office, Report on the Work of the Public Prosecutor's Offices for 2007, www. dorh. hr

\section{Romania}

[56] Avocatul Poporului, Annual Report 2008

[57] Baias, Flavius, Dumitrache Bogdan, Nicolae Marian, Regimul juridic al imobilelor preluate abuziv. Vol. I: Legea Nr. 10/2001 comentată şi adnotată (The Legal Situation of Nationalised Property. 1st Volume: Law 1/2001 discussed and annotated). Rosetti,

[58] Bucharest, 2001.

[59] Cartwright, Andrew, "Against 'de-collectivisation' land reform in Romania, 1990-1992", Max Planck Institute for Social Anthropology, Working Paper no. 4, Halle/Saale, 2000.

[60] Comisia Internationala pentru Studierea Holocaustului in Romania - Raport Final, Polirom 2005.

[61] Constantin, Florentina. Privatisation of Agriculture in Some East-European Countries (Hungary, Poland, Romania, Bulgaria). PhD Thesis, Academy of Economic Studies, Faculty of International Business and Economics, Dept History of Economy and Geography, 2005.

[62] European Commission, Regular Report from the Commission on Romania's Progress towards Accession, 1999

[63] European Commission, Regular Report from the Commission on Romania's Progress towards Accession, 2000.

[64] European Commission, Regular Report on Romania's Progress towards Accession, 2001

[65] European Commission, Regular Report on Romania's Progress towards Accession, 2003

[66] ECtHR "The Court Applies the Pilot-Judgement Procedure to Romanian Cases Concerning the Restitution of Properties Nationalised under Communism", press release no 158/25. 02. 2010. 
[67] lancu, G. "Aspecte din procesul colectivizării agriculturii în România (1949-1960)", Anuarul Institutului de Istorie din Cluj-Napoca, 2001.

[68] Interview with Damiana Oţoiu, researcher at the Institute for Political Studies of the Bucharest University, author of a PhD thesis (due in March 2010) on restitution of property to the Jewish community in Romania.

[69] Interview with the President of Proprietatea Fund, Bucharest, January 2010. Luca, Lucian. "Sectorul agroalimentar din Romania intr-o perspectiva europeana".

[70] Working Paper 39, World Bank, ECSSD, June 2005, Chap. 4.

[71] SAR, "Restituirea proprietăţii: De ce a ieşit aşa prost în România?". Policy Brief 34, 2008

[72] National Agency for Property Restitution, a response to a request based on Law 544/2001 on free access to public information. The data refer to end of 2009.

[73] Socaciu, E. M. Problema Dreptatii si Restituirea Proprietatii in Romania Post-comunista, (The Issue of Justice and Property Restitution in Post-Communist Romania). Doctoral Thesis, University of Bucharest.

[74] Stan, L. "The Roof over our Heads, Property Restitution in Romania", Journal of Communist Studies and Transition Politics, Vol. 22, No. 2, June 2006, pp. 180-205, 2006.

[75] Verdery K, 'Seeing like a Mayor, or How Local Officials Obstructed Romanian Land Restitution' Ethnography, Vol 3 (1): 5-33, 2002.

[76] World Bank Governance Indicators (1996-2008): http: //info. worldbank. org/governance/wgi/index. asp

\section{Serbia}

[77] Antic, Miroslav, "Kraj bajke o restitucij”, 10 March 2005, http: //www. mailarchive. com/sim@antic. org/msg22508. html

[78] Avakumović, M. , "Za restituciju od 102 do 221 milijarde evra", Politika Online,24/09/2009, http: //www. politika. rs/rubrike/tema-dana/Za-restituciju-od-102-do-221-milijarde-evra. sr. html

[79] Božić, Lj, Agrarian Policy with the basis of Agrarian Cooperatives, Sarajevo, 1963.

[80] Ćirković, B. Expropriation and Fair Compensation in Yugoslavian Law. Belgrade, 1979;

[81] Foreign Claims Settlement Commission, 2007 Annual Report,http: //www. usdoj. gov/fcsc/07rpt/annrep07. htm

[82] Glišić S, "The data analysis of deprived property files", Hereticus, Vol. VI (2008), No. I

[83] Kovačević, Nada, Branka, Mališ, "Srbija razgovara: Vraćanje nacionalizovane imovine", Politika Online, 20/04/2009, http: //www. politika. rs/rubrike/Drustvo/Srbija-razgovara- Vracanje-nacionalizovane-imovine. It. $\mathrm{html}$

[84] Lebl, Aleksandar, "Čija je imovina ubijenih Jevreja”, Politika Online, 29/07/2009

[85] http: //www. politika. rs/rubrike/ostali-komentari/CHija-je-imovina-ubijenih-Jevreja. It. html

[86] ***"Mreža za restituciju ocenjuje Nacrt zakona o restituciji i građevinskom zemljištu kao do sada najbolje ponuđeno rešenje", 15 May 2007, Pronadi Pravo,

[87] http: //www. pronadjipravo. com/index. php?link=opsirnije\&id=282\&table=vesti

[88] Malešević, LJ. , "Hotel "Putnik” prodat, naslednici tuže državu”, 20. 02. 2009, http: //www. naslovi. net/2009-0221/dnevnik/hotel-putnik-prodat-naslednici-tuzedrzavu/1048732

[89] Ministry of Finance, internal data.

[90] Mirković M, Economical History of Yugoslavia, Zagreb, 1968. 
[91] *** "Nacionalizovana imovina vredna do 220 milijardi evra", 24. 09. 2009, Biznis, http: //www. biznisnovine. $\mathrm{com} / \mathrm{cms} /$ item/stories/sr. html?view=story\&id=40149

[92] Statistical Office of the Republic of Serbia

[93] http: //webrzs. stat. gov. rs/axd/drugastrana. php?Sifra=0001\&izbor=odel\&tab=30

[94] Stevanović, Mirjana N. , "Oduzeta imovina sve dalja od bivših vlasnika", Danas. rs, 04/08/2009

[95] http: //www. danas. rs/vesti/ekonomija/oduzeta_imovina_sve_dalja_od_bivsih_vlasnika. 4. html?news_id $=168424$ 